\title{
PORTRAIT OF A POET: ERINNA'S EKPHRASTIC EPIGRAM, AP 6.352
}

\section{A Martin (Stellenbosch University)}

\begin{abstract}
Although we know very little about the young female poet, Erinna, it is evident from the reception of later Hellenistic epigrammatists that she was highly respected and contributed greatly to the advancement of the Hellenistic aesthetic. However, her pioneering role in the development, if not the establishment, of the literary ekphrastic epigram has long been overlooked in favour of her short hexameter poem and funerary epigrams on female lamentation and loss. This paper examines the numerous ways in which Erinna had contributed to the ekphrastic tradition and the manner in which her ekphrastic epigram $A P 6.352$ may have served as a prototype for later ekphrastic texts of the Hellenistic age.
\end{abstract}

Keywords: Hellenistic epigram, ekphrasis, female poets, visuality, artistic realism.

Of all the female poets who came after Sappho, Erinna - the 'maiden honey-bee' - is the most renowned in Greek antiquity. Yet very little is known about the circumstances surrounding her floruit, which can primarily be attributed to the fragmented nature of her extant texts and the small volume of her literary output. Much of the confusion and controversy surrounding the poet's life can also be ascribed to the contradictory information provided by the ancients concerning her

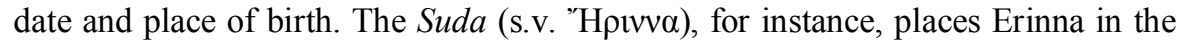
archaic period as a companion of Sappho, while Tatian (Ad. Gr. 33.1) sets her around the early $4^{\text {th }}$ century BC and Eusebius (Chron. Ol. 170.1) around 350 BC. ${ }^{2}$ The Suda further lists Telos, ${ }^{3}$ Teos, Rhodos, or Lesbos ${ }^{4}$ as her place of residence,

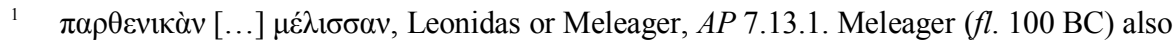

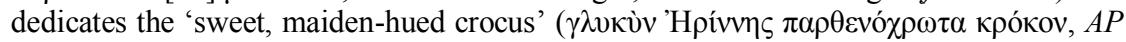
4.1.12) to Erinna in his garland of flowers for celebrated poets.

2 Scholars (e.g. Levaniouk 2008:200; Gutzwiller 2016:277, and Bowman 2019:77) have settled on a tentative date of 350-325 BC based on the poetic innovations noted in Erinna's work that are characteristically 'Hellenistic in their preoccupation with the minutiae of everyday life' (Levin 1962:193).

3 The Doric dialect in which Erinna composed makes Telos or Rhodes a more likely option than the Ionian city of Teos or Tenos, or the Aeolian island of Lesbos (Barnard 1978:204; Plant 2004:51, n.2; Gutzwiller 2016:278).

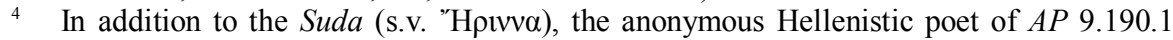

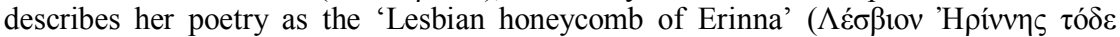

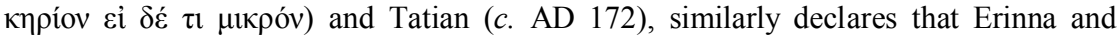

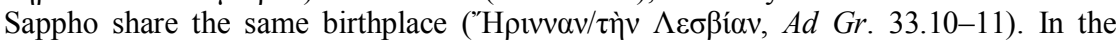


and a later ekphrastic epigram $(A P 2.108)$ by Christodorus $\left(5^{\text {th }}-6^{\text {th }}\right.$ centuries AD)

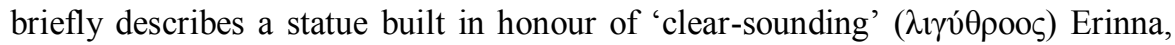
which perished in a fire around AD 532. Even her identity as a woman poet has been challenged by ancient and modern scholars alike (e.g. Athenaeus $7.283 \mathrm{~d}$ and West 1977) on the premise that her poetry was simply too sophisticated to have been authored by an uneducated woman from a small, rural island. ${ }^{6}$ The only information that seems fairly undisputed about Erinna's life, is her death at the early age of nineteen when 'Hades snatched her away to be his bride' ('Aı $\delta \alpha \varsigma$ عi $\zeta$

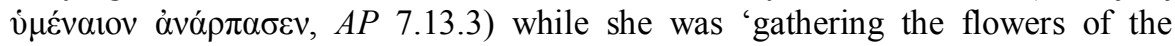

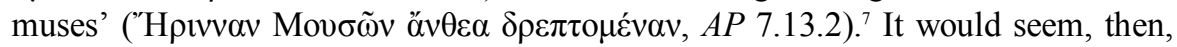
that the poet's portrait has remained incomplete.

Despite the lack of biographical information on Erinna, her reception among Hellenistic poets and scholars can only be described as overwhelmingly positive, with much of her praise attributed to the short but concise nature of her lines, a literary skill that had garnered much acclaim among Callimachean grammatici. ${ }^{8}$ An anonymous epigram, for instance, describes the 'honeycomb'

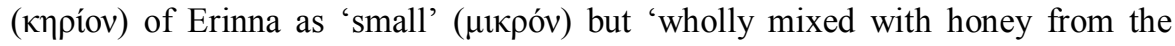

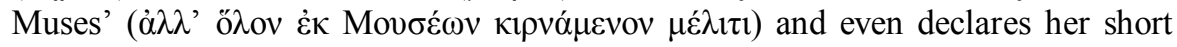

caption to her epigram $A P 7.710$ (later added by male scribes), Erinna is also referred to as 'Hpívm however, but should rather be recognised as male poets' tendency to connect female poets to their great poetic predecessor, Sappho (as can also be noted in the captions to

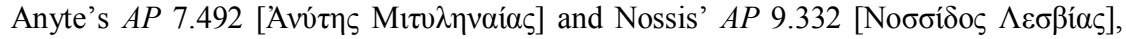
even though none of these women were from Lesbos). See Gow \& Page 1965.1:41, 97 and 152.

$5 \quad$ See De Vos 2014:426.

6 See Pomeroy 1978 and Arthur 1980 who challenge West's 1977 proposal that the real author of Erinna's hexameter poem was a male poet writing under a female pseudonym. Such an argument does, however, disregard the increase in women's education and literacy for which the Hellenistic age is known, especially when one considers that Teos, one of Erinna's proposed provenances, allowed young women access to education in public schools (Syll. ${ }^{3}$ 578). See also Pomeroy 1977:51-69, 1984:59-82 and Gutzwiller 2007:195-201 on women's education in the Hellenistic age.

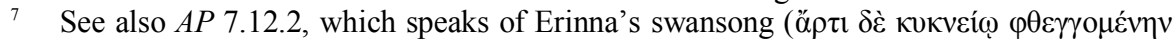
$\sigma \tau$ ó $\mu \alpha \tau$ ), calling upon the ancient belief that swans sing right before they die; Chrysippus in Athenaeus 14.616b; Plb. 30.4.7; see Arnott 1977:149.

8 See Callimachus Aitia, fr. 1.21-28 and AP 12.43 on keeping your muse 'slender' $\left(\lambda \varepsilon \pi \tau \alpha \lambda \varepsilon_{\varepsilon} \circ \varsigma\right)$, i.e. on writing in short and concise lines. Antiphanes (AP 11.322), one of the few male poets to look unfavourably upon Erinna, evokes her name in his battle against the 'miserable bookworms' ( $\dot{\alpha} \tau \chi \chi \varepsilon \tilde{\varepsilon} \varsigma$ $\sigma \tilde{\eta} \tau \varepsilon \zeta, 2)$ of the pro-Callimachean camp who preen themselves over their knowledge of her work. 


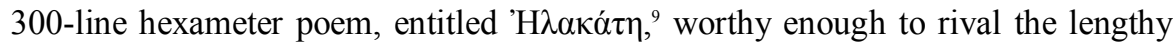

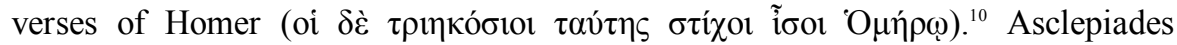

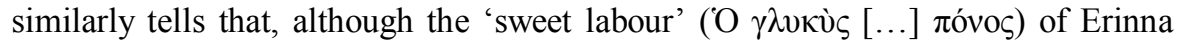
may not be much due to her premature death, it is 'more powerful than many

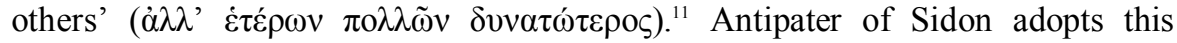
association of brevity with Erinna's poetry; she is a 'writer of few words', he

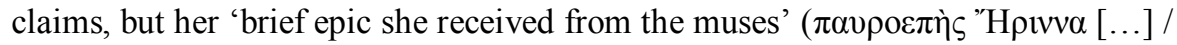

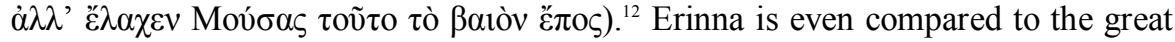
Mytilenean poet, Sappho, whose lyric verses surpass Erinna inasmuch as Erinna

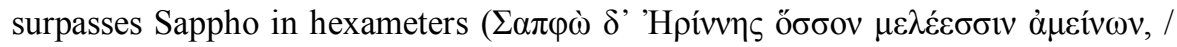

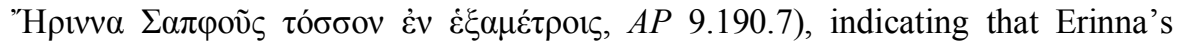
works were highly praised and the poet herself greatly respected by later Hellenistic poets for her innovative lines, as few as they were.

In addition to her hexameter poem and two funerary epigrams $(A P 7.710$ and 7.712) - all of which mournfully recall Erinna's childhood memories and lament the marriage, death and funeral of her dearest friend, Baukis - the female epigrammatist produced a third and final epigram, ${ }^{13} A P$ 6.352, which is the only preserved poem in the poet's oeuvre to diverge from the Bavkís narrative. In this epigram, the poet moves away from a very personal account of grief and loss to the vibrant celebration of life, poetry, and artistic verisimilitude. Erinna describes the portrait of a young woman whose likeness is captured with such precision that the

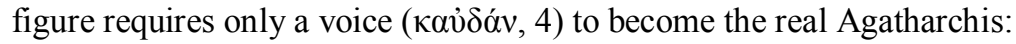

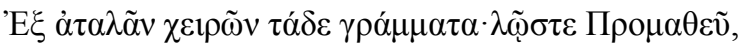

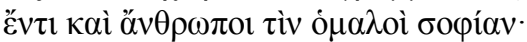

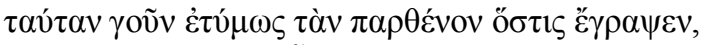

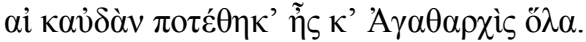

From delicate hands this portrait is fashioned: good Prometheus,

There are humans equal to you in skill also.

Whoever drew this girl so true-to-life,

9 The distaff, PSI 1090. Unfortunately, only 54 lines of the 300-line hexameter poem have been recovered. See Gutzwiller 1997:205 for a text of the fragment.

10 Anon. $A P$ 9.190.1-3.

11 AP 7.11.1,3.

12 AP 7.713.1-2.

13 The Hellenistic epigram ( $\dot{\varepsilon} \pi \dot{\gamma} \gamma \rho \alpha \mu \mu \alpha)$ is a short poem consisting primarily of elegiac couplets. Where once it predominantly appeared as funerary and dedicatory epigrams inscribed on monuments, temples and tombs, the Hellenistic literary epigram saw an expansion in theme, including sympotic, epideictic and ekphrastic categories. For treatments of the Hellenistic epigram see Bing \& Bruss 2007 and Henriksén 2019. 
If he had but added a voice, you would have been Agatharchis complete. $^{14}$

$A P 6.352$ has been generally overlooked by scholarship in favour of the poignant tune of Erinna's lamentations. As a result, Erinna's smallest epigram seems to have 'slipped through the cracks', a disconnected part of a larger whole. Recent scholarship has, however, attempted to correct this oversight by investigating the way in which Erinna's epigram delivers commentary on the 'gendered voice' and 'modes of viewing' often expressed in Greek poetry. ${ }^{15}$ Yet rarely is her epigram

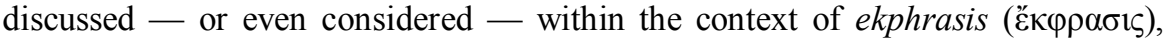
even though it has been argued that Erinna's $A P 6.352$ is, putatively speaking, the first ekphrastic epigram to be preserved (Skinner 2001:207 and Männlein-Robert 2007:255), ${ }^{16}$ or, at the very least, the first ekphrastic epigram to 'use a female perspective to interrogate a work of art' (Bowman 2019:79). Although it would be difficult to prove conclusively, Erinna probably played a crucial role in the transition from poetic performance to Hellenistic textuality ${ }^{17}$ and subsequently had a decisive impact on the alteration of the inscriptional (dedicatory) epigram into the literary epigram ${ }^{18}$ that provided innovative commentary on the relationship between 'text' and 'image'. It is not surprising then, that Gutzwiller (2002:89) regards Erinna as a forerunner of Hellenistic aesthetics and her ekphrastic epigram as a 'direct model for scenes of ecphrasis' in later Hellenistic poetry. In fact, it is quite possible, even probable, that later Hellenistic poets allude to Erinna's ekphrastic epigram as an innovative model when they employ the elements

14 Gow \& Page 1965:1.98. Translations from the Greek texts are my own, unless indicated otherwise. For commentary or alternative translations on AP 6.352, see Snyder 1989:90; Balmer 1996:63; Plant 2004:51; Rayor 1991:124, 2005:69; Manwell 2005:86; Goldhill 2007:11; Männlein-Robert 2007:255; Squire 2015:13; Gutzwiller 2016:280-282, 2017:320; and Bowman 2019:79.

15 Manwell 2005:86-87 and Männlein-Robert 2007:256 discuss the superiority of the poet over that of the visual artist (or the 'plastic arts'), who cannot endow the portrait with a voice as the poet is able to, while Rayor 2005:69 interprets the epigram as a commentary on how the written word lacks the potency of the spoken word (or performed song) associated with Sappho. Murray \& Rowland 2007:226 argue that Erinna's contribution to Hellenistic poetry lies in her articulation of the 'transgendered' voice, and a study by Gutzwiller 2017:320-321 investigates traces of the lyric tradition observed in Erinna's $A P$ 6.352, particularly with relevance to the Hellenistic poet's use of poetic voice and the subjective nature of her lines.

16 Goldhill 2007:11, n. 30 is more cautious in his phrasing, suggesting that Erinna's $A P$ 6.352 is 'a very early example of ekphrastic epigram', albeit, not necessarily the first. His uncertainty stems from the confusion surrounding Erinna's date.

17 Rayor 2005:60, 70.

18 See Gutzwiller 2002:86-91. 
(i) Ětvuos ('true-to-life', 3), (ii) Prometheus as mythological forebearer, and (iii) the addition of voice only to complete mimesis,${ }^{19}$ further supporting the likelihood of Erinna's contribution to the ekphrastic epigram. This paper therefore examines Erinna's pioneering role as a precursor of the ekphrastic subtype, and an innovative contributor to the far-reaching tradition of ekphrasis in general.

To investigate Erinna's short poem as poetic model for the Hellenistic ekphrastic epigram, it is first necessary to determine what is understood with the term ekphrasis. It was only around the $1^{\text {st }}$ century AD that a distinct definition of ekphrasis was first recorded in Theon's Progymnasmata, the orator's training manual on the art of rhetoric: 'Ekphrasis is a descriptive speech that manifests the

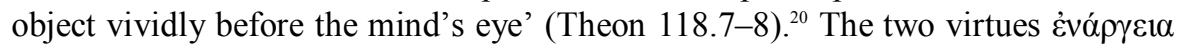
(vividness) and $\sigma \alpha \varphi \eta$ veı $\alpha$ (clarity) therefore regularly made an appearance within the context of ancient ekphrasis (Goldhill 2007:4; Francis 2009:3; Zeitlin 2013:17; Führer and Banaszkiewicz 2014:48, 53; Squire 2015:4 and 2018:373). However, unlike its modern interpretation, ekphrasis originally encompassed more than simply visualised objects of art, also describing abstract concepts such as 'deeds'

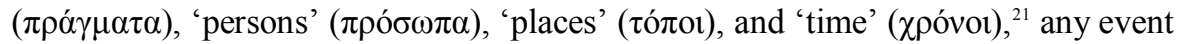
or thing that is described with such vivid detail that the speaker is transformed into a 'spectator' $(\theta \varepsilon \alpha \tau \dot{\alpha} \varsigma)^{22}$ who is 'seeing through hearing'. ${ }^{23}$ Ancient ekphrasis was thus approached as a rhetorical technique rather than a literary genre (Francis 2009:4), one that focused specifically on the relationship between artifice and reality, as well as the verbal and the visual. ${ }^{24}$ It is, then, not so much the described object or event that takes centre stage in the ekphrastic text but the response of the audience (Webb 1999:12; Zeitlin 2013:18; Führer and Banaszkiewicz 2014:50),

19 On ekphrasis and the mimetic tradition, see Bram 2006:372-378.

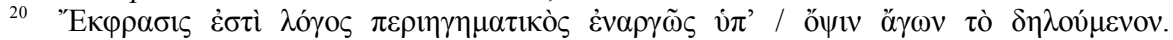
Etymologically speaking, ekphrasis can be translated as 'speaking out', or to 'tell in full'

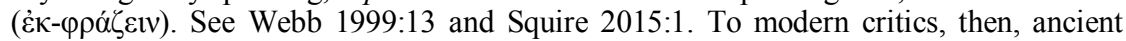
ekphrasis has come to represent a process that 'embraces the creative activity of imagination by both the speaker or writer and the recipient to bring about a fictive presence of an absent object or scene' (Führer \& Banaszkiewicz 2014:54), or, simply put, ekphrasis is a 'verbal representation of a visual representation' (Heffernan 1993:3).

21 Theon Progym. 118.8-9.

22 Nicolaus Progym. 70.6.

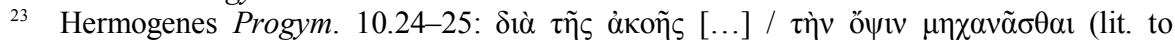
conjure up a 'visual image' through hearing).

24 The dichotomy between poetry and painting, between that which is said, and that which is seen - and how the latter is shaped by the former - had been an ancient topic; Plutarch, for instance, quotes Simonides saying that 'painting is silent poetry, and poetry

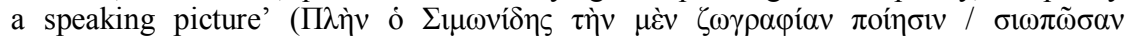

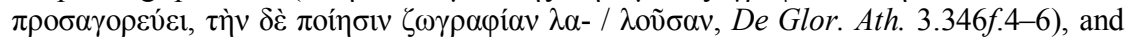
Horace claims that 'as is painting, so is poetry' (Ut pictura poesis, Ars. P. 361). 
and the skill of the rhetorician who, through $\varphi \alpha v \tau \alpha \sigma i \alpha,{ }^{25}$ conjures the unseen with such exactness that it nearly manifests itself physically before the audience's imaginary vision. ${ }^{26}$

Although the term ekphrasis was not yet in circulation during Erinna's age, the virtues that lie at the heart of it can already be observed as far back as Homer's Iliad when the epic poet depicts Hephaistos' manufacture of the shield of Achilles (Il. 18.468-608) with a descriptive energy that makes for highly provocative imagery. ${ }^{27}$ The soldiers engraved in the shield, for example, 'battled like living

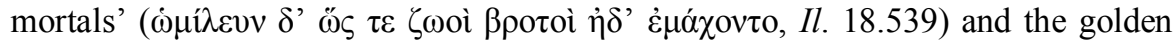

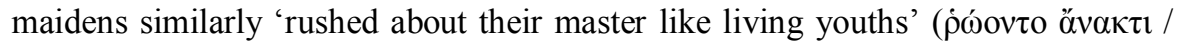

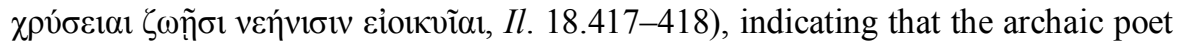
composed his lines with a vivacity that breathed life into the metallic figures. This technique of artistic verisimilitude was then adopted by Hesiod, who writes that Hephaistos set aside his metal for clay (Theog. 571) when he fashioned

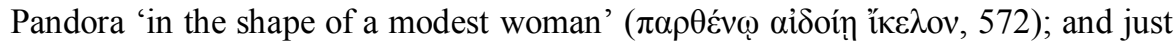
as Homer's metallic maids gained 'voice and vigour' ( $\alpha$ ỏ 420 ), just so the gods brought the terracotta maiden to life by giving her speech and

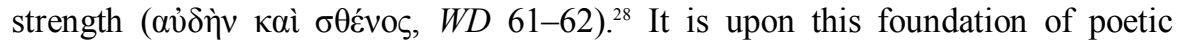
realism that the "literary genre ${ }^{29}$ of ekphrasis was supposedly born, and within this early period that the ekphrastic tradition was initially established.

${ }^{25} \varphi \alpha v \tau \alpha \sigma i \alpha=$ the power by which an object or image $(\varphi \alpha ́ v \tau \alpha \sigma \mu \alpha)$ is presented. See Aristotle De anima 428a, 1-4.

26 For more on ancient ekphrasis, see Heffernan 1993; Goldhill 1994; Elsner 2002; and Squire 2013.

27 This particular section from Homer's Iliad has been deemed the first instance of ekphrasis in Western literature (Francis 2009:8) and Homer himself a 'lover of

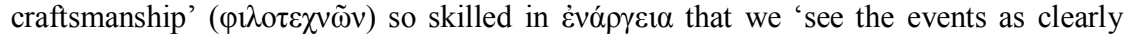
when they are described to us as if they were actually happening' (

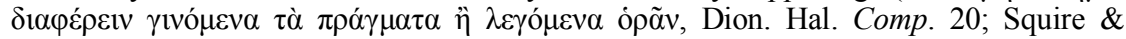
Elsner 2016:60-61).

28 On Homer's 'Shield of Achilles' and Hesiod's 'Creation of women' as the beginning of ekphrasis, see Francis 2009:13.

29 This paper tentatively refers to ancient ekphrasis as a 'poetic genre', since such an approach to descriptive literature is a fairly modern concept. See Webb 1999:17, who argues that ekphrasis has been 'divorced from its rhetorical background and reinterpreted as a poetic genre stretching not only backwards to Homer and Theocritus, but also forward to the nineteenth century'. However, Gutzwiller 2002:85, n. 1 reminds that, although descriptive texts on artwork did indeed make an appearance in earlier

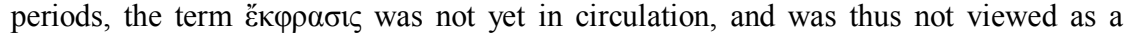
distinct literary genre; nevertheless, by the Hellenistic age, these descriptive texts on artworks were distinguishable enough in theme and technique to justify a separate category in epigrammatic collections, e.g. Agathias, $A P$ 4.3.117-120 and The new

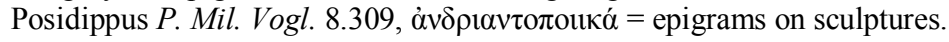


In typical Hellenistic fashion, Erinna's ekphrastic epigram seems to draw upon these earlier literary traditions and techniques, while simultaneously putting her own innovative stamp on her work. The female poet may call upon Homer (Il. 10.534; Od. 19.203), Hesiod (Th. 27), Aeschylus (Eum. 534), and Plato's

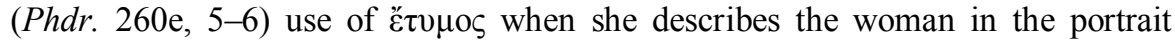

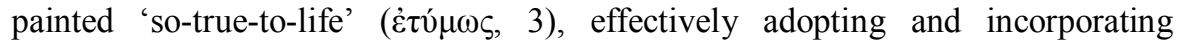
previous impressions of 'truth', 'naturalism', or 'realism' into the context of ekphrasis as a standard of artistic 'truth' and 'accuracy'. Erinna's specific use of $\dot{\varepsilon} \tau u ́ \mu \omega \varsigma$ suggests a conscious decision to allude to earlier notions of artistic realism, but within the newer genre of the Hellenistic epigram. However, within her own use of the genre, Erinna does not vividly describe how this artistic verisimilitude manifests, as the reader is not provided with a detailed description of the portraited individual. The brief nature of the epigram does not, after all, afford much room

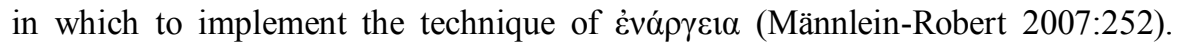
Erinna's poem therefore brings about a significant transformation within ekphrasis - the shift from a vivid narration ${ }^{30}$ of events and circumstances (i.e. actions, movements, and speech), to the brief description of a single work of art (i.e. immobile and silent). ${ }^{31}$ In other words, her ekphrastic epigram moves away from the broad technique of enargeia (visual vividness) ) $^{32}$ to the narrowly-defined

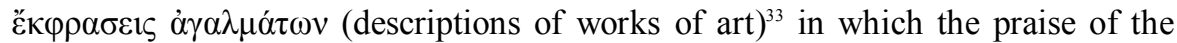
artwork, albeit fabricated, now takes precedence, ${ }^{34}$ and, subsequently, the visualising process of the viewer, who observes, identifies and reflects upon the 'aesthetic excellence' and 'mimetic force ${ }^{35}$ of a work of art. Therefore, it is perhaps better to argue that it is not so much a case of Erinna lacking enargeia in her work as her work interrogating exactly what is understood by 'vivid perception' in the first place. ${ }^{36}$

Yet another allusion to earlier 'ekphrastic' poetry that Erinna implements in her own style, is the notion of a lifeless object recreated so true to life as to lack

30 On ekphrasis as a vivid account of an event or circumstance, see Heffernan 1991 and Koopman 2018:15-31.

31 In special cases (e.g. $C E G$ 190, 326), inscribed dedicatory epigrams of the archaic age endowed the dedicated object with a voice; this particular epigram type (i.e. the 'speaking object' epigram) eventually makes an appearance in the literary dedicatory epigram of the Hellenistic era (e.g. Callimachus' AP 6.149), but lies beyond the scope of this study. See Schmitz 2010:29-31 and Gutzwiller 2017:322-323.

32 Zanker 2003:59-62 and Männlein-Robert 2007:252.

33 See Zanker 2004:6.

34 See Goldhill 1994:205 and Gutzwiller 2002:86, 88.

35 Gutzwiller 2002:86.

36 Squire 2015:13 addresses this important point in his section 'Vision and voice in "ecphrastic" epigram'. 


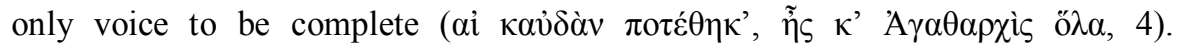
In a fragment from one of Aeschylus' satyr plays (fr. 78a.1. 5-7 TrGF), the satyr chorus comments on their true likeness captured on masks soon to be dedicated in a temple:

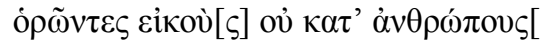

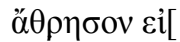

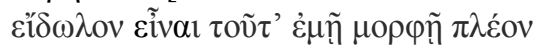

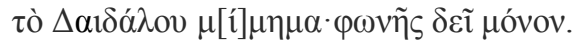

Seeing images not made by humans ...

Observe if[

this image reflected

could possibly be more in likeness to me.

Daedalus' work - it needs only a voice.

Various similarities can be observed between the words in the Aeschylean fragment and Erinna's ekphrastic epigram: both poets comment on the divine skill of the artist and both poets emphasise the lack of a voice that renders the artistic object 'incomplete'. ${ }^{37}$ However, whereas Aeschylus' play was composed for the purpose of performance, Erinna introduces a novel idea by establishing ekphrastic moments within a purely written form - the literary epigram, 'written to be read' (Schmitz 2010:25). ${ }^{38}$ Erinna serves as a stylistic precursor by merging the dedicatory qualities of the inscriptional epigram, ${ }^{39}$ such as providing the name of the dedicator (Agatharchis), with new content (Gutzwiller 2002:90-91), in this case the description of an artwork and the visualising experience of the 'viewer' or the 'seeing subject'. ${ }^{40}$ Where once early inscribed dedicatory epigram displayed a first-person voice that ventriloquised the object itself, or a third-person voice in the form of the artist, patron, or composer of the dedicated object, the early literary epigram typically provides the viewer with the poetic voice so that it may deliver commentary on the 'perceptual process' involved in examining the artwork and

37 See Skinner 2001:207-208 and Gutzwiller 2002:89, 2016:281.

38 The Hellenistic epigram was likely the ideal genre in which to ensure the alteration and preservation of the ekphrastic tradition, since it was not only renowned for its short lines and versatile nature ( $\pi \mathrm{o} \lambda \nu \varepsilon i ́ \delta \varepsilon 1 \alpha=$ 'many-formed-ness'/ 'generic versatility'), but also formed part of the 'bookish' or literary era, the hallmark of the Hellenistic age, that circulated poems among private audiences in the form of epigrammatic collections and Hellenistic anthologies, ensuring its dissemination and survival. See Gutzwiller 1998:3, 6; 2002:86-87 and Rayor 2005:60.

39 See Gutzwiller 2002:86 and 2017:321 on Erinna's AP 6.352 as a fusion of the 'dedicatory category with the ekphrastic subtype'.

40 Goldhill 1994:86. 
so that the spectator of the visualised image may articulate an appropriate interpretation or response..$^{41}$ This literary strategy can be observed in Erinna's own ekphrastic epigram when she employs the eye of the viewer to validate the mimetic talent of the artist and the artificial truth of the artwork; her short poem adopts the voice and perspective of the 'spectator' who proceeds to address the portrait ('you would have been Agatharchis complete', $\tilde{\eta} \varsigma$ א' A A $\gamma \alpha \theta \alpha \rho \chi i \varsigma ~ o ̈ \lambda \alpha, 4)$ as if it is the woman herself, effectively bringing Agatharchis to life without the need for lengthy verses and extreme vividness. Erinna also omits the name of the artist and the identity of the dedicatee that previously served as identification markers for the dedicatory epigram to construct a novel epigram form in which the 'excellence of the painting and the girl who is its subject' (Gutzwiller 2017:320) become the poet's primary objective. It is plausible, then, that Erinna's earlier ekphrastic epigram played a critical role in the poetic progression from the inscriptional dedicatory epigram to the literary ekphrastic epigram, and the subsequent shift in voice and artistic subject that accompanied this literary development. ${ }^{42}$

Further evidence for Erinna's ground-breaking role in the ekphrastic epigram occurs in the form of her significant interplay between 'text' and 'image', a concept that can already be observed with the inscriptional epigram as part text (inscription) and part image (object upon which the text is inscribed). This intricate relationship between poet and painter within the context of ekphrasis is best portrayed by Erinna's use of the verb है $\gamma \rho \alpha \psi \varepsilon v$ (3), which had previously been utilised by poets (e.g. Hdt. 2.41.5; Aesch. Eum. 50; Plat. Rep. 377e2) to refer not only to the act of writing, but also to the act of painting. By manipulating the 'dual semantic register' ${ }^{43}$ of $\gamma \rho \alpha \dot{\varphi} \varphi \varepsilon ı v$, the female poet establishes a powerful relationship between text and image in her epigram, augmented by Erinna's use of $\gamma \rho \alpha \dot{\mu} \mu \mu \tau \alpha$ (1), typically translated as 'letters' but utilised here to suggest 'portrait' (Plat. Rep. 472d.6; Herod. Mim. 4.73). 'Written lines' and 'drawn lines' are thus used indiscriminately at first, with such clever proficiency that it only becomes clear in line 3, when the poet mentions the $\pi \alpha \rho \theta \dot{\varepsilon} v o \zeta$, that the poet is actually

${ }^{41}$ See Gutzwiller 2002:86 on the evolution of the epigram's poetic voice throughout the different ages of Greek antiquity.

42 It can also be argued that Erinna was one of the first early Hellenistic poets to introduce subjective elements into the formerly conventional, 'rough' epigram model, gradually shifting this genre from its sub-literary (Gebrauchspoesie) public function to 'the purposes of poetic pleasure' (Gutzwiller 2017:319). For the first time in Greek literature, state Gutzwiller \& Michelini 1991:73, romantic life becomes the dominant topic and 'children, animals, rustics, the bourgeois - all act as central characters; heroes or gods, when present, are juxtaposed with the humble'. Emphasis now shifts from the 'grand and weighty', to the 'delicate and intricate', much like the praise of an otherwise unknown, voiceless girl in Erinna's ekphrastic epigram.

43 Squire 2018:358. 
referring to a painted portrait and not a written document. ${ }^{44}$ Good Prometheus does not reveal Erinna's poetic playfulness too soon either, for the god was not only humanity's sculptor, but also the Titan to gift mankind with writing $(\gamma \rho \alpha \mu \mu \alpha \dot{\tau} \omega \mathrm{v}$ $\sigma v v \theta \dot{\varepsilon} \sigma \varepsilon 1 \varsigma$, Aesch. $P B$ 460-461). Erinna's epigram is therefore a commentary on the close relationship between the verbal and the visual and the poet as vehicle in merging the two: the written characters $(\gamma \rho \alpha \dot{\alpha} \mu \alpha \tau \alpha)$ of the poem and the drawn lines $(\gamma \rho \alpha \dot{\mu} \mu \alpha \tau \alpha)$ of the portrait collapse into one and the same thing, and by extension, so does the poet and the artist. ${ }^{45}$ Erinna becomes the painter with the 'delicate'/ 'youthful hands', a subtle reminder of the elegant and refined style of her verses (Männlein-Robert 2007:255) that immortalised her name and declared

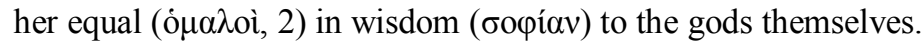

It has been argued that Erinna's pioneering role in the ekphrastic tradition also manifests in the form of her significant influence on later Hellenistic epigrammatists that served as a model for similar later ekphrastic scenes. ${ }^{46}$ Theocritus (early $3^{\text {rd }}$ century BC), for instance, dabbles in ekphrasis (Idyll 15.80$84)^{47}$ when one of his characters, Praxinoa, stares in awe at the beautiful craftmanship of an embroidery, praising the artists for how intricately and precisely they 'drew the patterns' ( $\gamma \rho \alpha \dot{\mu} \mu \alpha \tau$ ' है $\gamma \rho \alpha \psi \alpha \nu, 81)$, for 'how truly they stand' ( $\dot{\omega} \varsigma$

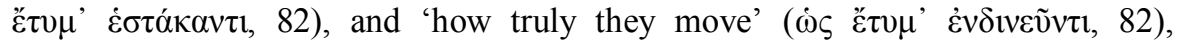

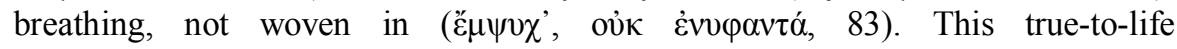
representation of the artwork can be interpreted as an adaptation of Erinna's own ekphrastic style, as can be attested by Theocritus' repetition of the word हैं that has previously been associated with Erinna and the ekphrastic tradition she evokes. Theocritus' allusion to Erinna's ekphrastic epigram can further be observed in his reference to the (in)human skill involved in creating such vivid

44 See Meyer 2007:190, who persuasively argues that written characters are in some respects comparable to the 'reading' of a picture, to the point that 'readers of inscriptions and viewers of portraits in Hellenistic epigrams are represented analogously'.

45 The independent circulation of literary ekphrastic texts - as 'self-standing poetic entities [...] collected in their own literary right' (Gutzwiller 2002:86) - has been argued to only strengthen the rivalry between image and text, word and picture, and poet and artist (see e.g. Gutzwiller 2002:91 and Männlein-Robert 2007:256). With the epigram no longer attached to its physical object, there is a noticeable shift in power towards the medium of poetry, for now the composer becomes both poet and 'painter'. For a contradictory viewpoint, see Koopman 2018:9, who describes the relationship between the verbal and visual as complimentary in nature.

46 See Gow \& Page 1965:2.284; Snyder 1989:91; Skinner 2001:206-221; Gutzwiller 1997:214, 2002:281, 2016:88; and Bowman 2019:79.

47 Another noteworthy instance of Theocritean ekphraseis occurs in the poet's programmatic Idyll 1 (27ff), which contains a detailed description of various scenes carved into a wooden cup. 


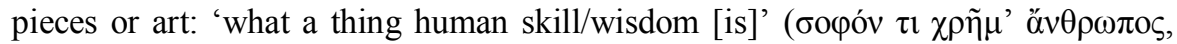
83), a likely imitation of Erinna's own praise towards the artist with the delicate

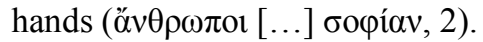

Herodas' Mimiambi 4 (mid. $3^{\text {rd }}$ century BC) similarly adopts Erinna's ekphrastic style when two of his female characters visiting Asclepius' temple at Cos examine a sculpture of a boy strangling a goose, declaring it so lifelike, so true to nature, that one would expect at any moment for the stone to speak ( $\dot{\varepsilon} \rho \varepsilon i \bar{\zeta}$, $\lambda \alpha \lambda \eta \dot{\sigma \varepsilon 1}, 33)$, echoing the silence of Erinna's own lady in the portrait. The women continue to exclaim that 'in time, human wisdom will put life into the stone'

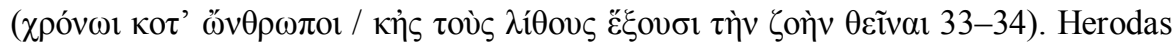
then turns the reader/spectator's attention towards another piece of art, a statue of a woman named Batale, whose cold likeness one only has to gaze upon to know the

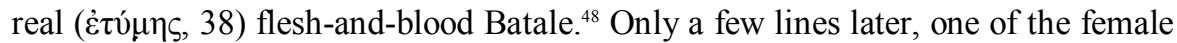
spectators, Kokkale, brings about an instance of enargeia (Skinner 2001:219) when she describes the image before her with such a severe intensity that the viewer struggles to conjure the near tangible image before the mind's eye (4.59-62):

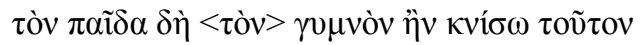

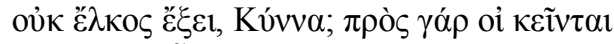

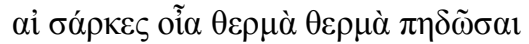

$\dot{\varepsilon} \vee \tau \tilde{\eta} 1 \sigma \alpha v i ́ \sigma \kappa \eta 1$.

This boy, the naked one, if I should scratch him,

Would he not bleed, Kynno? For in the panel,

The flesh rests on him, pulsing like hot, hot springs.

It is possible that Herodas exaggerates the artistic realism of the artworks in his Book 4 as a comic slight against Erinna, ${ }^{49}$ but even if this is the case, Herodas' regular evocation of Erinna's ekphrastic style only serves as a testimony to the important role the young woman played in further developing the ekphrastic tradition and the significant influence she had on the works of later poets and on the Hellenistic aesthetic in general.

Nossis (fl. c. $300 \mathrm{BC}$ ) is yet another poet renowned for her use of the ekphrastic technique. Like Erinna before her, Nossis vividly describes the portraits

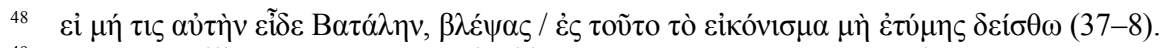

49 See Gutzwiller 1998:74-75 and Skinner 2001:216-221 on Herodas' Mim. 6.20-34; 7.57-58, in which the poet establishes a familial connection between Erinna and Nossis — the former as the latter's mother — but then proceeds to associate Nossis with leather dildoes ( $\beta \alpha v \beta \omega ́ v, 6.20)$. This malicious association, according to Skinner 2001:221 and Bowman 2019:79, only serves to verify how present the female poetic influence was within the Hellenistic poetic tradition for it to warrant such a severe attack from Herodas in the first place. 
of young women (e.g. AP 6.353, 6.354, 9.604, 9.605) and employs Erinna's descriptive technique with a vibrancy that has often caused scholars to erroneously attribute Erinna's ekphrastic epigram to her poetic descendent. ${ }^{50}$ In $A P$ 6.353, Nossis invites the reader/spectator to observe how truly ( $\dot{\varepsilon} \varsigma \dot{\varepsilon} \tau \dot{\omega} \mu \omega \varsigma$, 4) the

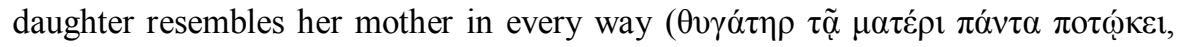
4); the close resemblance between her ekphrastic epigram and that of Erinna's can especially be noted in the way Nossis' $A P 6.353$ was placed directly after Erinna's $A P 6.352$ in Meleager's epigrammatic collection. Although Meleager's original layout was eventually disrupted by scribes and editors of late antiquity, a very distinct arrangement was noted by modern scholars: ${ }^{51}$ firstly, poems by more prolific poets recur in a rhythmical alternation with the works of less renowned poets. Secondly, the epigrams are grouped according to subject-matter, with the younger poets imitating the original poets, and verbal parallels or lexical echoes

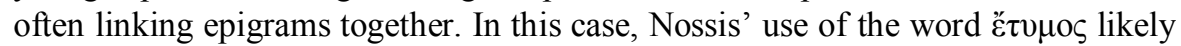
functioned as the lexical bridge that tied these two ekphrastic epigrams together, suggesting that, two centuries later, ancient Greek poets and scholars could still recognise Nossis' imitation of Erinna's ekphrastic style..$^{52}$

Posidippus ( $3^{\text {rd }}$ century BC) adopts Erinna's ekphrastic technique in one of his ekphrastic epigrams, going well beyond a simple description of a bronze statue that the artist Hecataeus had created with 'all his skill' (ő $\lambda[\eta 1] \ldots \tau \dot{\varepsilon} \chi v \eta 1,5)$ by

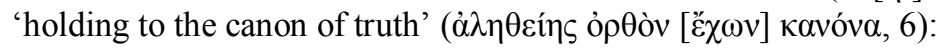

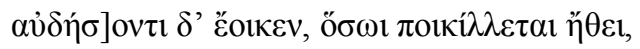

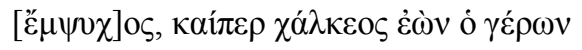

He looks as one on the precipice of speech, embellished with such character,

Breathing, although the old man is made of bronze. ${ }^{53}$

50 West 1977:115, for example, disputes Erinna's authorship of AP 6.352 and attributes it instead to Nossis who is renowned for her ekphrastic epigrams. Gow \& Page 1965:2.284, on the other hand, suggest that Erinna served as a model for Nossis' subsequent ekphrastic style.

51 Gow \& Page 1965:xviii; Gutzwiller 1997:171; Argentieri 2007:156; and Maltomini 2019:216.

52 See also Nossis' $A P$ 9.604, which speaks of yet another woman, Thaumareta, whose form ( $\mu$ орфóv) had been captured so thoroughly by the artist that even her pride ( $\tau$ ò $\gamma \alpha \tilde{u} \rho \circ v)$ and youthfulness ( $\tau$ ó $\omega \rho \alpha \tilde{o} o v)$ were recreated. Moreover, even the painted woman's watchdog puppy is fooled by the almost identical copy of the girl, and barks in

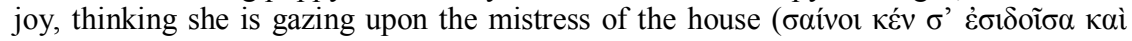

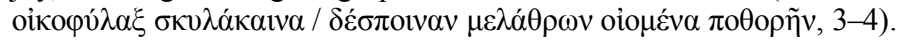

${ }^{53}$ P. Mil. Vogl. 8.309, 63 AB, 7-8. See Sens 2005:209. 
As in Erinna's epigram, the poet comments on an artwork so expertly recreated that it only requires speech to become the real model. Erinna's influence on Posidippus' ekphrastic epigram can also be observed by the way in which the male poet comments on the skill $(\tau \dot{\varepsilon} \chi v \eta 1,5)$ of the artist that can almost achieve the divine abilities of the gods by endowing stone with life ([ع̈ $\mu \psi v \chi] \circ \varsigma, 8)$. Nevertheless, as wise as the sculptor may be, the particularly realistic bronze statue remains an inanimate object, its inability to speak one of the 'essential deficits' (Männlein-Robert 2007:259) of ekphrasis. This ekphrastic deficit ${ }^{54}$ can also be noted in Book 9 of the Palatine Anthology, which consists of epideictic and ekphrastic epigrams, ${ }^{55}$ many specifically on Myron's bronze statue of a heifer (AP 9.713-9.742). Antipater's $A P 9.724$ is of particular importance to this study, as it is rich in its allusions to Erinna's ekphrastic epigram. So vividly made is Myron's cow, claims the speaker, that the bronze animal is about to 'moo'

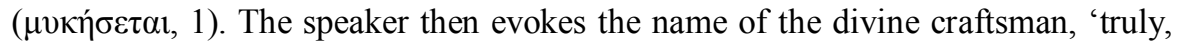
Prometheus ( $\dot{0} \Pi \rho \circ \mu \eta \theta \varepsilon \dot{v} \varsigma, 1)$ is not the only one to breathe life into things, but you also, Myron' ${ }^{56}$ a possible allusion to Erinna's own reference to Prometheus $(\lambda \tilde{\omega} \sigma \tau \varepsilon$ $\Pi \rho 0 \mu \alpha \theta \varepsilon \tilde{v}, 1)$, the archetype of artistic creativity, as the divine standard by which the mortal skill of the artist (or, more specifically, the epigrammatist) ${ }^{57}$ is measured and judged equal.

A final contribution worth noting in this paper is Erinna's development of the 'gendered voice' within the ekphrastic subgenre. Recent scholarship ${ }^{58}$ has argued that Erinna introduces to ekphrasis a feminine voice and novel female perspective that ultimately evolved into a 'female ekphrastic tradition' in its own right. This scholarly position further postulates that women were among the first to compose ekphrastic epigrams and did so in a way that 'appropriated conventional "viewing" situations and dialogue from mime and drama for the purpose of creating a female visual perspective' (Skinner 2001:202). However, Goldhill (2007:11) convincingly points out that every aspect of Erinna's poem, be it her

54 Christodorus $A P$ 2.108-110 captures this 'deficit' well when he refers to the real Erinna

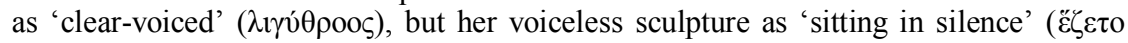

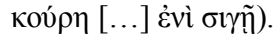

55 It is often difficult to distinguish between the epideictic and ekphrastic epigram, but their primary difference lies in the former's more pedagogical and rhetorical nature, while the latter has a tendency to take a work of art as its subject and is generally less detailed and analytical, see Männlein-Robert 2007:251-252.

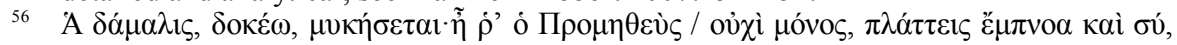
Múpov. See also $A P 9.719$ and $A P 9.793$.

57 See Murray \& Rowland 2007:224 on the significance of Prometheus in Erinna's ekphrastic epigram.

58 E.g. Skinner 2001; Gutzwiller 2002, 2016; Manwell 2005; Murray \& Rowland 2007; and Bowman 2019. 
language, structure, or argument, can be observed within the ekphrastic tradition predominantly associated with male poets, such as praising the craftmanship ( $\tau \dot{\varepsilon} \chi \vee \eta)$ of the poet, evoking the name of Prometheus, commenting on the wisdom

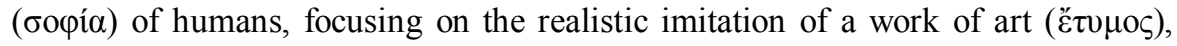
and voicing the conundrum of endowing an artwork with a voice. One can therefore prompt the question, on which grounds other than gender do we distinguish women's poetry from men's? Earlier discussions on this topic have likewise been raised on the poetry of Sappho, whose 'sexual predilections' (Lardinois 1989:23) have become an integral part of her poetic fame. This obsessive focus on Sappho's gender has only served to consign the poet to a private, exclusively female world, despite the fact that the lyric poet wrote in genres and themes similar to her male peers. ${ }^{59}$ In a similar manner, we should recognise that Erinna's influence on the ekphrastic tradition is not inherently bound to her gender, but is rather a consequence of the female writer's poetic skill and innovative literary techniques that inspired the works of many epigrammatists who succeeded her, be they male or female.

This paper investigated the ways in which Erinna's ekphrastic epigram likely served as a prototype for ekphrasis within later Hellenistic texts, especially within the genre of the literary epigram. A cursory glance into later Hellenistic poetry reveals an ekphrastic trend of sorts that can be traced back to Erinna's

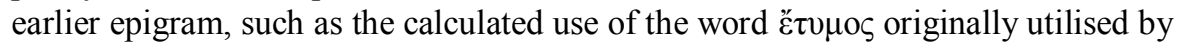
Erinna to comment on the artistic verisimilitude of the artist (or poet), the focus on mankind's wisdom and ingenuity in artistic creations, and Prometheus as the ultimate craftsman and critic of humanity's skill and technique. Such regular reference to Erinna's AP 6.352 certainly supports the view that Erinna was highly influential in the development of the ekphrastic epigram, but it is especially her transformation of the inscribed dedicatory epigram into the literary descriptive epigram that should justify her title as a progenitor of this Hellenistic subgenre. Erinna plays an important part in 'freeing' an item from the physical location to which it was formerly bound, moving its function from dedicated object to artistic subject, from tangible image to visualised image, thus introducing new insights into Hellenistic Greece's 'culture of viewing'. Where once there was little need to

59 Hallett 1979:463, for example, points out that Alkman's works have generally been perceived as 'choral public works', while Sappho's poetry has been relegated to 'personal, privately voiced statements from an eccentric female'. Lardinois 1989:20 asserts that Sappho's poetry is 'conventional in character', despite the poet's female gender, and Parker 2005:4 claims that the private Sappho 'lends herself so very easily to certain ideas much discussed in feminist poetics and politics' (e.g. a woman-centred poetry and a female-only poetic tradition). As a result, Sappho's works on public genres and themes did not receive as much attention in scholarship as her more 'feminine' texts did. 
fashion a vivid description of an inscribed object the viewers could physically observe for themselves, it was now required of the Hellenistic epigrammatist to construct an abstract image that may replace the one of metal and stone. In so doing, the visualised image might be independently circulated for the pleasure of the reader, ultimately transformed into the viewer who is "perceiving, analysing, and reacting to ${ }^{60}$ the described artwork as if though he or she were a traveller passing by the bronze statue, stone monument or painted portrait. Erinna's $A P$ 6.352 played a crucial role in this visualising process, reigniting in other poets a similar need to write within a brief, but realistic vein that renders the physical presence of the interrogated artwork inconsequential, allocating her an undeniable place in the far-reaching ekphrastic tradition of Greek antiquity.

\section{BIBLIOGRAPHY}

Argentieri, L 2007. Meleager and Philip as epigram collectors. In Bing, P \& Bruss, J S (eds.), Brill's companion to Hellenistic epigram, 147-164. Leiden: Brill. Arnott, W G 1977. Swan songs. G\&R 24.2:149-153.

Arthur, M B 1980. The tortoise and the mirror: Erinna PSI 1090. $C W 74.2: 5365$.

Balmer, J (trans.) 1996. Classical women poets. Newcastle: Bloodaxe Books.

Barnard, S 1978. Hellenistic women poets. CJ 73.3:204-213.

Bing, P \& Bruss, J S (eds.) 2007. Brill's companion to Hellenistic epigram. Leiden: Brill.

Bowman, L 2019. Hidden figures: The women who wrote epigrams. In Henriksén, C (ed.), A companion to ancient epigram, 77-92. Medford, MA: Wiley.

Bram, S 2006. Ekphrasis as a shield: Ekphrasis and the mimetic tradition. Word \& Image 22.4:372-378.

De Vos, M 2014. From Lesbos she took her honeycomb: Sappho and the 'female tradition' in Hellenistic poetry. In Ker, J \& Pieper, C (eds.), Valuing the past in the Greco-Roman world: Proceedings from the Penn-Leiden Colloquia on Ancient Values VII, 410-434. Leiden: Brill.

Elsner, J 2002. Introduction: The genres of ekphrasis. Ramus 31.1:1-18.

Francis, J A 2009. Metal maidens, Achilles' shield, and Pandora: The beginnings of 'ekphrasis'. AJPh 130.1:1-23.

Führer, H \& Banaszkiewicz, B 2014. The trajectory of ancient ekphrasis. In Jedličková, A (ed.), On description, 45-75. Praha: Akropolis.

Goldhill, S 1994. The naive and knowing eye: Ecphrasis and the culture of viewing in the Hellenistic world. In Goldhill, S \& Osborne, R (eds.), Art and text in ancient Greek culture, 197-223. Cambridge: Cambridge University Press.

${ }^{60}$ Gutzwiller 2017:319. 
2007. What is ekphrasis for? $C P$ 102.1:1-19.

Gow, A S F \& Page, D L 1965. The Greek anthology: Hellenistic epigrams, Vols. $1 \& 2$. London: Cambridge University Press.

Gutzwiller, K \& Michelini, A N 1991. Women and other strangers: Feminist perspectives in Classical literature. In Hartman, J E \& Messer-Davidow, E (eds.), (En)gendering knowledge: Feminists in Academe, 66-84. Knoxville: University of Tennessee Press.

Gutzwiller, K 1997. Genre and gender in Erinna and Nossis. In Prins, Y \& Shreiber, M (eds.), Dwelling in possibility: Women poets and critics on poetry, 202-222. Ithaca \& London: Cornell University Press.

1998. Poetic garlands: Hellenistic epigrams in context. Hellenistic culture and society. Berkeley \& California: University of California Press.

2002. Art's echo: The tradition of Hellenistic ecphrastic epigram. In Harder, A, Regtuit, R F, \& Wakker, G C (eds.), Hellenistic epigrams, 85-112. Louvain: Peeters.

2007. A guide to Hellenistic literature. Malden, MA: Blackwell.

2016. Erinna. In Sider, D (ed.), Hellenistic poetry: A selection, 277-287. Ann Arbor: University of Michigan Press.

2017. Lyricism in Hellenistic epigram. Trends in Classics 9.2:317-338.

Hallett, J P 1979. Sappho and her social context: Sense and sensuality. Signs 4.3:447-464.

Heffernan, J A W 1991. Ekphrasis and representation. New Literary History 22.2:297-316.

1993. Museum of words: The poetics of ekphrasis from Homer to Ashbery. Chicago \& London: University of Chicago Press.

Henriksén, C (ed.) 2019. A companion to ancient epigram. Medford, MA: John Wiley \& Sons.

Koopman, N 2018. Ancient Greek ekphrasis: Between description and narration: Five linguistic and narratological case studies. Leiden: Brill.

Lardinois, A 1989. Lesbian Sappho and Sappho of Lesbos. In Bremmer, J (ed.), From Sappho to De Sade: Moments in the history of sexuality, 15-35. New York \& London: Routledge.

Levaniouk, O 2008. Lament and hymenaios in Erinna's Distaff. In Suter, A (ed.), Lament: Studies in the ancient Mediterranean and beyond, 200-232. Oxford \& New York: Oxford University Press.

Levin, D N 1962. Qvaestiones Erinneanae. HSPh 66:193-204.

Maltomini, F 2019. Greek anthologies from the Hellenistic age to the Byzantine era: A survey. In Henriksén, C (ed.), A companion to ancient epigram, 211227. Medford, MA: Wiley. 
Männlein-Robert, I 2007. Epigrams on art: Voice and voicelessness in ecphrastic epigram. In Bing, $\mathrm{P} \&$ Bruss, J S (eds.), Brill's companion to Hellenistic epigram, 251-271. Leiden: Brill.

Manwell, E 2005. Dico ergo sum: Erinna's voice and poetic reality. In Greene, E (ed.), Women poets in ancient Greece and Rome, 72-90. Norman: University of Oklahoma Press.

Meyer, D 2007. The act of reading and the act of writing in Hellenistic epigram. In Bing, P \& Bruss, J S (eds.), Brill's companion to Hellenistic epigram, 187210. Leiden: Brill.

Murray, J \& Rowland, J M 2007. Gendered voices in Hellenistic epigram. In Bing, P \& Bruss, J S (eds.), Brill's companion to Hellenistic epigram, 211-232. Leiden: Brill.

Parker, H 2005. Sappho's public world. In Greene, E (ed.), Women poets in ancient Greece and Rome, 3-24. Norman: University of Oklahoma Press.

Plant, I M (trans.) 2004. Women poets of ancient Greece and Rome: An anthology. Norman: University of Oklahoma Press.

Pomeroy, S B 1977. Technikai kai mousikai: The education of women in the fourth century and in the Hellenistic period. AJAH 2:51-68. 1978. Supplementary notes on Erinna. ZPE 32:17-22.

1984. Women in Hellenistic Egypt: From Alexander to Cleopatra. New York: Schocken Books.

Rayor, D J 1991. Sappho's lyre: Archaic lyric and women poets of ancient Greece. Berkeley: University of California Press.

-2005. The power of memory in Erinna and Sappho. In Greene, E (ed.), Women poets in ancient Greece and Rome, 59-71. Norman: University of Oklahoma Press.

Schmitz, T A 2010. Speaker and addressee in early Greek epigram and lyric. In Baumbach, M, Petrovic, A, and Petrovic, I (eds.), Archaic and classical Greek epigram, 25-41. Cambridge: Cambridge University Press.

Sens, A 2005. The art of poetry and the poetry of art: The unity and poetics of Posidippus' statue-poems. In Gutzwiller, K (ed.), The new Posidippus: A Hellenistic poetry book, 206-225. Oxford: Oxford University Press.

Skinner, M B 2001. Ladies' day at the art institute: Theocritus, Herodas, and the gendered gaze. In Lardinois, A \& McClure, L (eds.), Making silence speak: Women's voices in Greek literature and society, 201-222. Princeton: Princeton University Press.

Snyder, J M 1989. Women poets of Hellenistic Greece: Anyte, Nossis, Moero, and Erinna. In The woman and the lyre: Women writers in classical Greece and Rome, 64-98. Bristol: Bristol Classical Press. 
Squire, M J 2013. Ekphrasis at the forge and the forging of ekphrasis: The 'Shield of Achilles' in Graeco-Roman word and image. Word \& Image 29:157-191.

2015. Ecphrasis: Visual and verbal interactions in ancient Greek and Latin literature. Oxford Handbooks Online, DOI: 0.1093/oxfordhb/9780199935390.013.58 (21 May 2020).

2018. A picture of ecphrasis: The younger Philostratus and the Homeric shield of Achilles. In Kampakoglou, A \& Novokhatko, A (eds.), Gaze, vision, and visuality in ancient Greek literature, 357-417. Berlin: Walter de Gruyter.

Squire, M J \& Elsner, J 2016. Homer and the ekphrasists: Text and picture in the elder Philostratus' 'Scamander' (Imagines 1.1). In Bintliff, J \& Rutter, K (eds.), The archaeology of Greece and Rome: Studies in honour of Anthony Snodgrass, 57-99. Edinburgh: Edinburgh University Press.

Watson, P 2019. A gallery of characters: Real persons and fictitious types in epigram. In Henriksén, C (ed.), A companion to ancient epigram, 43-58. Medford, MA: Wiley.

Webb, R 1999. Ekphrasis ancient and modern: The invention of a genre. Word \& Image 15.1:7-18.

West, M L 1977. Erinna. ZPE 25:95-119.

Zanker, G 2003. New light on the literary category of 'ekphrastic epigram' in antiquity: The new Posidippus (Col. X 7-XI 19 P. Mil. Vogl. 8.309). ZPE 143:59-62.

2004. Modes of viewing in Hellenistic poetry and art. Wisconsin: Wisconsin University Press.

Zeitlin, F I 2013. Figure: Ekphrasis. $G \& R$ 60.1:17-31. 